Ceramic Vessel Sherds from the Kah-Hah-Ko-Wha Site (41CE354), an Allen Phase Component in Northwestern Cherokee County, Texas

Timothy K. Perttula

Heritage Research Center, Stephen F. Austin State University

Follow this and additional works at: https://scholarworks.sfasu.edu/ita

Part of the American Material Culture Commons, Archaeological Anthropology Commons, Environmental Studies Commons, Other American Studies Commons, Other Arts and Humanities Commons, Other History of Art, Architecture, and Archaeology Commons, and the United States History Commons

Tell us how this article helped you.

This Article is brought to you for free and open access by the Center for Regional Heritage Research at SFA ScholarWorks. It has been accepted for inclusion in Index of Texas Archaeology: Open Access Gray Literature from the Lone Star State by an authorized editor of SFA ScholarWorks. For more information, please contact cdsscholarworks@sfasu.edu. 
Ceramic Vessel Sherds from the Kah-Hah-Ko-Wha Site (41CE354), an Allen Phase Component in Northwestern Cherokee County, Texas

\section{Creative Commons License}

\section{(c) (1) (8)}

This work is licensed under a Creative Commons Attribution-NonCommercial 4.0 International License 


\title{
Ceramic Vessel Sherds from the Kah-Hah-Ko-Wha Site (41CE354), an Allen Phase Component in Northwestern Cherokee County, Texas
}

\author{
Timothy K. Perttula
}

\section{INTRODUCTION}

The Kah-hah-ko-wha site (41CE354) is an Historic Caddo Allen phase (ca. A.D. 1650-1800) habitation site situated in an upland saddle landform in the Flat Creek valley in the upper Neches River basin of East Texas. Flat Creek flows west a few kilometers to its confluence with the Neches River, not far downstream of Lake Palestine. The site was found and investigated as part of survey and test excavation investigations for a proposed U.S. Army Corps of Engineers-permitted lake on Flat Creek in northwestern Cherokee County (Perttula and Nelson 2007).

During those 2006 investigations, a large assemblage of Allen phasc Caddo ceramics were recovered from household areas in the North and Alley parts of the site (Pcrttula and Nelson 2007:Figure 31), making it one of the very few upper Neches Historic Caddo Allen phase domestic sites ever studied (e.g., Cole 1975). As such, a detailed analysis of the domcstic ceramics found at the Kah-hah-ko-wha site provides a unique opportunity to document the ceramic practices and traditions of these Caddo peoples.

Ceramic vessel sherds are abundant at the Kahhah-ko-wha site, with 474 decorated sherds and 94 plain sherds from at least 36 vessels (based on the number of recovered rim sherds). The density of ceramic vessel sherds is 16.9 per $\mathrm{m}^{2}$ in the North area excavation units $(\mathrm{n}=213)$ and 37.0 per $\mathrm{m}^{2}$ in the Alley area $(n=314)$. The plain/decorated sherd ratio (P/DR) for the site as a whole is only 0.20 , quite comparable with the Allen phase component at the Deshazo site (Story 1995; Fields 1995), where the P/DR is 0.29 , and the $18^{\text {th }}$ century Nabedache Azul and Nabedache Blanco sites in the Neches River basin, Houston County (Perttula and Nelson 2006:62); the P/DR ranges from 0.31-0.32 at these sites. By area, the P/DR in the North area is 0.31 , compared to 0.13 from the Alley area.

The lower P/DR from the Alley area suggests this occupation may be slightly younger than the North area occupation, even though the calibrated radiocarbon dates from the site do not suggest this (see Perttula and Nelson 2007:Table 1). Table 1 provides comparative sherd assemblage data from nearby Lake Palestine sites on the Neches River (see Anderson et al. 1974) and the Lang Pasturc site (41AN38, Kelley et al. 2006), about five miles southwest from the Kah-hah-ko-wha site.

In this particular seriation, the Kah-hah-kowha site lalls in Group I of the seriation, and is interpreted as the youngest or most recent known Caddo occupation of the Lake Palcstine arca sites. By the late 17th and 18th centuries other Caddo sites are known in the Neches and Angelina river basins where brushed sherds account for ca. 50-90\% of all the decoratcd sherds, which is consistent with the fact that more than $82 \%$ of the sherds at the Kahhah-ko-wha site are brushed.

\section{DECORATED VESSEL SHERDS}

The 474 decorated sherds from the test excavations at the Kah-hah-ko-wha site are grouped into 10 utility ware decorative classes and two fine ware decorative classes (Table 2). Utility ware sherds comprise $88.2 \%$ of all the decorated sherds and $62 \%$ of the decorated rim sherds. Utility wares generally are jars and simple bowls used for the cooking and storage of foods, as well as food serving, have a coarse temper, and usually lack burnishing, polishing, or slipping on interior and exterior vessel surfaces. Such vessel sherds are decorated with brushing and other wet paste decorative methods, including incising, punctations, appliqued, and neck banded elements, either by themselves or in combination with one or more of these decorative methods. Fine wares, on the other hand, consist principally of engraved and slipped vessel sherds from carinated bowls, bottles, and some simple bowls that were used for food serving and the holding of liquids. The fine ware vessels and vessel sherds more frequently are well-smoothed. 
Table 1. Comparative sherd assemblage data from Lake Palestine, nearby Caddo sites, and the Kah-hahko-wha site (41CE354).

\begin{tabular}{|c|c|c|c|c|c|c|}
\hline Site & No. of Dec. & $\begin{array}{l}\text { \% Brushed } \\
\text { Sherds }\end{array}$ & $\begin{array}{l}\text { \%bone- } \\
\text { temper }\end{array}$ & $\begin{array}{l}\text { \% Wet-paste } \\
\text { decorations }\end{array}$ & P/DR & $\begin{array}{c}\text { Brushed/Wet } \\
\text { paste ratio }\end{array}$ \\
\hline \multicolumn{7}{|c|}{ YOUNGEST SITES: GROUP I } \\
\hline 41CE354 & 474 & 82.7 & 3.1 & 8.9 & 0.20 & 8.14 \\
\hline Debro & 311 & 80.0 & $?$ & 10.3 & 0.14 & 7.75 \\
\hline William Sherman & 525 & 75.8 & $?$ & 16.2 & 0.44 & 4.68 \\
\hline \multicolumn{7}{|l|}{ GROUP II } \\
\hline Forest Drive & 1693 & 68.6 & $?$ & 21.9 & 0.56 & 3.12 \\
\hline Halbert & 1757 & 65.8 & 2.6 & 26.3 & 0.70 & 2.51 \\
\hline Woldert & 1730 & 62.7 & 0.0 & 28.8 & 0.72 & 2.19 \\
\hline Ferguson & 4116 & 60.8 & $<1.0$ & 27.9 & 0.61 & 2.17 \\
\hline \multicolumn{7}{|l|}{ GROUP III } \\
\hline Tomato Patch & 912 & 49.2 & $?$ & 41.7 & 1.50 & 1.21 \\
\hline Lang Pasture & 2435 & 35.9 & 6.7 & 38.0 & 1.40 & 0.91 \\
\hline Mitchell, D & 54 & 32.1 & 0.0 & 33.3 & 1.37 & 1.50 \\
\hline \multicolumn{7}{|l|}{ GROUP IV } \\
\hline White Mule & 1404 & 18.5 & 1.5 & 63.7 & 2.61 & 0.29 \\
\hline 41HE139 & 40 & 17.5 & 8.1 & 65.0 & 2.51 & 0.33 \\
\hline \multicolumn{7}{|c|}{ OLDEST SITE: GROUP V } \\
\hline Mitchell, A-C & 56 & 1.3 & 12.0 & 65.7 & 1.71 & 0.03 \\
\hline
\end{tabular}

burnished, or polished on the exterior surface, and have finer temper inclusions and thinner vessel walls than do the utility wares. The fine wares were made, fired, and used in different ways than the utility wares (see below). About $12 \%$ of the vessel sherds are from fine wares, including $38 \%$ of the decorated rim sherds (Table 2).

The dominance of brushed vessels (Bullard Brushed jars) in the Kah-hah-ko-wha vessel sherd assemblage is clear in the decorated sherd information presented in Table 2 . Almost $74 \%$ of all the decorated sherds have brushing on either the rim and body of utility ware jars, and the abundance of both brushed rims and body sherds suggests that most of the vessel surface on utility ware jars was covered with brushing marks.

Brushing also occurs in association with punclated, appliqued, incised, and neck banded utility ware decorations (see Table 2). These decorative classes comprise another $9.1 \%$ of the decorated sherds from the site. The virtual absence of rim sherds among these decorative classes (there is one brushed-punctated rim) indicates that these particular combinations of decorative elements were confined to the vessel bodies of utility ware jars. In the case of the neck banded-brushed La Rue Neck Banded sherd, the neck banding is on the rim or neck of a jar and the brushing was applied vertically on the vessel body (see Suhm and Jelks 1962:Platc 47a, c-d). The incised $(3.8 \%)$, punctated $(0.6 \%)$, and appliqued $(1.1 \%)$ vessel sherds appear to have had similar decorative elements on both the rim and vessel bodies, although they also occur in combination with brushing on jar bodies. These particular decoration classes represent only a very minor aspect of the decorated utility wares from the Kah-hah-ko-wha site.

The one red-slipped sherd is from a bowl that has a hematite-rich clay slip only on its exterior vessel surface. The engraved fine wares have engraved decorations on the rim of carinated bowls and simple 
Table 2. Decorated sherds.

\begin{tabular}{lccc}
\hline Decorative Class & Rim Sherds & Body Sherds & N \\
\hline Utility Ware & & & \\
Brushed & 13 & 336 & 349 \\
Brushed-Incised & - & 26 & 26 \\
Incised & 2 & 16 & 18 \\
Brushed-Punctated & 1 & 9 & 10 \\
Appliqued & 1 & 4 & 5 \\
Punctated & 1 & 2 & 3 \\
Brushed-Punctated-Incised & - & 3 & 3 \\
Brushed-Appliqued & - & 2 & 2 \\
Brushed-Punctated-Appliqued & - & $\mathrm{I}$ & 1 \\
Neck Banded-Brushed & - & 1 & 1 \\
Subtotal & 18 & 400 & 418 \\
& & & \\
Fine Ware & & 44 & 55 \\
Engraved & 11 & 1 & 1 \\
Red-slipped & - & 445 & 474 \\
\hline Totals & 29 & & \\
\hline
\end{tabular}

bowls as well as engraved decorations over most of the body of bottle vessel forms.

There are important differences in the kinds and relative abundance of the different vessel sherd decorative classes between the Alley and North areas (Table 3). The meaning (or meanings) of these differences is explored in the concluding part of this article. One of the main differences are that the frequency of brushed sherds is almost $20 \%$ higher in the Alley area than it is in the North area. All sherds with brushing (including those with other decorative clements, such as brushed-punctated) comprise $86 \%$ of the Alley area sherds and $76.7 \%$ from the North area. Utility ware brushed vessels with combinations of brushing and other decorative elements are more common in the North area, however, particularly vessel body sherds with brushed-incised and brushed-punctated decorations. Brushed-appliqued and brushed-punctated-incised body sherds are found only in the Alley area.

Utility ware vessels decorated with incised elements (probably from Maydelle Incised jars) are more than twice as common in the North area as they are among the decorated sherds in the Alley area (see Table 3). Appliqued and punctated vessel sherds are restricted to the Alley area, even though they only account for $2.5 \%$ of the area's decorated sherds.

Fine ware engraved and red-slipped sherds are much more abundant in the North area (17.2\%) than they are in the Alley area (8.6\%) (see Table 3), even though Patton Engraved and Poynor Engraved vessel sherds are present in both areas. Hume Engraved vessel sherds are found only in the Alley area.

In addition to the decorated sherds from the North and Alley areas, five decorated sherds have been recovered in limited investigations in the Southern area (see Perttula and Nelson 2007:Figure 30 ). These sherds include two parallel brushed body sherds, one parallel brushed-incised body sherd, another sherd with a row of tool punctations, and a bottle sherd with closely-spaced curvilinear engraved lines.

\section{Fine Wares}

The fine ware sherds include 56 sherds, 11 of which are rim sherds (Table 4). The one 
Table 3. Decorated sherds from the $1 \times 1 \mathrm{~m}$ units in the North and Alley areas.

\begin{tabular}{|c|c|c|}
\hline Decorative Class & Alley area & North area \\
\hline \multicolumn{3}{|l|}{ Utility Ware } \\
\hline Brushed & $77.8^{*}$ & 66.3 \\
\hline Brushed-Incised & 5.0 & 6.1 \\
\hline Incised & 2.9 & 6.1 \\
\hline Brushed-Punctated & 1.4 & 3.7 \\
\hline Appliqued & 1.8 & 0.0 \\
\hline Punctated & 0.7 & 0.0 \\
\hline Brushed-Punctated-Incised & 1.1 & 0.0 \\
\hline Brushed-Appliqued & 0.7 & 0.0 \\
\hline Brushcd-Punctated-Appliqued & 1.1 & 0.0 \\
\hline Neck Banded-Brushed & $0.0+$ & 0.0 \\
\hline \multicolumn{3}{|l|}{ Fine Ware } \\
\hline Engraved & 8.6 & 16.6 \\
\hline Red-slipped & 0.0 & 0.6 \\
\hline Totals & 279 & 163 \\
\hline
\end{tabular}

*percentage; + the one neck banded-brushed sherd in the collection is from a shovel test excavated in the Alley area

red-slipped sherd is from the North area. Three different engraved types are present in the fine ware assemblage: Patton Engraved, Humc Engraved, and Poynor Engraved (Figures 1d-g and 2a-f). Patton Engraved sherds are the most abundant of the fine wares, comprising $37.7 \%$ of the engraved sherds from the Alley area and $60.6 \%$ of the North area engraved fine wares. The Hume Engraved sherds $(16.7 \%)$ were only found in the Alley area, while 4.2-7.1\% of the engraved sherds arc from Poynor Engraved vessels in the two areas. The latter sherds are from the later PP variety of Poynor Engraved defined by Kleinschmidt (1982:Figure 20 and Table 19).

The Patton Engraved sherds are dominated by those with either triangular or linear tick marks on horizontal (the most common element), diagonal, or curvilinear engraved lines on vessel rims (see Figure ld-g). Triangular tick-marked examples are more common than linear ticks in both site areas, and are slightly more prevalent in the Alley area (75\% of the tick marks on Patton Engraved sherds are triangular-shaped, compared to $67 \%$ from the North area). One linear tick-marked Patton Engraved sherd from the North area has a white kaolin pigment in the engraved lines. At the Deshazo site, occupied as late as ca. $\mathrm{AD} 1720$, more than $93 \%$ of the Patton Engraved sherds have the triangular tick-marked element (Fields 1995:187, 189).

Other Patton Engraved decorative elements include a small engraved circle (see Figure 2b) without tick marks on one body sherd (see Kleinschmidt 1982:Figure 20). The sherd is from the Alley area. Sherds with broad curvilinear engraved lines, likely part of a concentric circle motif, are also included in the Patton Engraved ceramics from the site; one of these sherds from the North area has a white kaolin clay pigment smeared in the engraved lines. Suhm and Jelks (1962:Plate 59d. h-i, k) and Fields (1995:Figure 64f-g) illustratc vessels and sherds with broad curvilinear lines on the body of bowls and olla-like forms, and with horizontal engraved lines on the rim with triangular tick marks.

The sherds classified as Hume Engraved (see Figure $2 \mathrm{a}, \mathrm{c}$ ) are found only in the Alley area. They are rim and body sherds that have large hatched or excised triangles that are pendant from horizontal engraved lines (see Suhm and Jelks 1962:Plate 42b-c). According to Kleinschmidt (1982:Table 
Table 4. Decorative classes and elements identified in the fine ware sherds.

\begin{tabular}{llll}
\hline $\begin{array}{l}\text { Decorativc Class } \\
\text { and Element }\end{array}$ & Alley ared & North area & Other \\
\hline
\end{tabular}

\section{Red-slipped}

Ext. red-slipped body

$-\quad 3.6^{*}$

\section{Engraved, Patton Engraved}

Circular element, body

Broad horizontal line-

Triangular tick marks

Horizontal line and

Triangular tick mark, body

Horizontal line and

Triangular tick mark, rim

Parallel engraved lines with

Triangular tick marks, body

Curvilinear lines with

Triangular tick marks, body

Single straight line with

Triangular tick marks, body

Triangular tick mark, body

Horizontal line and linear

Tick mark, body

Horizontal line and linear

Tick mark, rim

Horizontal-diagonal lines

and linear ticks, body

Parallel lines and linear

Tick narks, body

Linear tick mark, body

Broad curvilinear line, body

Broad curvilinear lines,

Widely-spaced, body

\section{2}

$-$

4.2

$-$

$-$

$-$

4.2

4.2

$-$

-

$-$

4.2

12.5

4.2

\section{Engraved, Hume Engraved}

Horizontal engraved and

Pendant triangles, rim

Broad line and excised

Pendant triangle, body

\section{Engraved, Poynor Engraved}

Broad horizontal and

Opposed lines, rim

Broad curvilinear and

Horizontal lines, rim

\section{Engraved, bottle sherds}

Multiple curvilinear lines, body
4.2

$-$
$25.0^{* *}$

3.6

7.1

3.6

7.1

7.1

$-$

$25.0^{* *}$

7.1

$-$

10.7

7.1

$25.0+$

$-$

$-$ 
Table 4. (Continued)

\begin{tabular}{lccc}
\hline $\begin{array}{l}\text { Decorative Class } \\
\text { and Element }\end{array}$ & Alley area & North area & Other \\
\hline $\begin{array}{l}\text { Closely-spaced curvilinear } \\
\text { lines, body } \\
\text { cross-hatched and horizontal } \\
\text { lines, body }\end{array}$ & - & - & $25.0 \#$ \\
Hatched zone, body & 4.2 & - & - \\
Other Engraved elements & 4.2 & & - \\
$\begin{array}{l}\text { Horizontal lines and lip } \\
\text { notched, rim }\end{array}$ & & 3.6 & - \\
$\begin{array}{l}\text { Single slanting line, rim } \\
\text { Cross-hatched lines, body } \\
\text { Widely spaced parallel lines, body }\end{array}$ & 4.2 & 3.6 & - \\
$\begin{array}{l}\text { Closely-spaced parallel lines, body } \\
\text { Widely spaced opposed lines, body }\end{array}$ & - & - & - \\
Single broad straight line, body & 12.5 & 7.1 & - \\
\hline \begin{tabular}{l} 
Totals \\
\hline
\end{tabular} & 24 & 3.6 & - \\
\hline
\end{tabular}

*percentage $* *$ North area, surface, +Alley area shovel test, \#South area shovel test

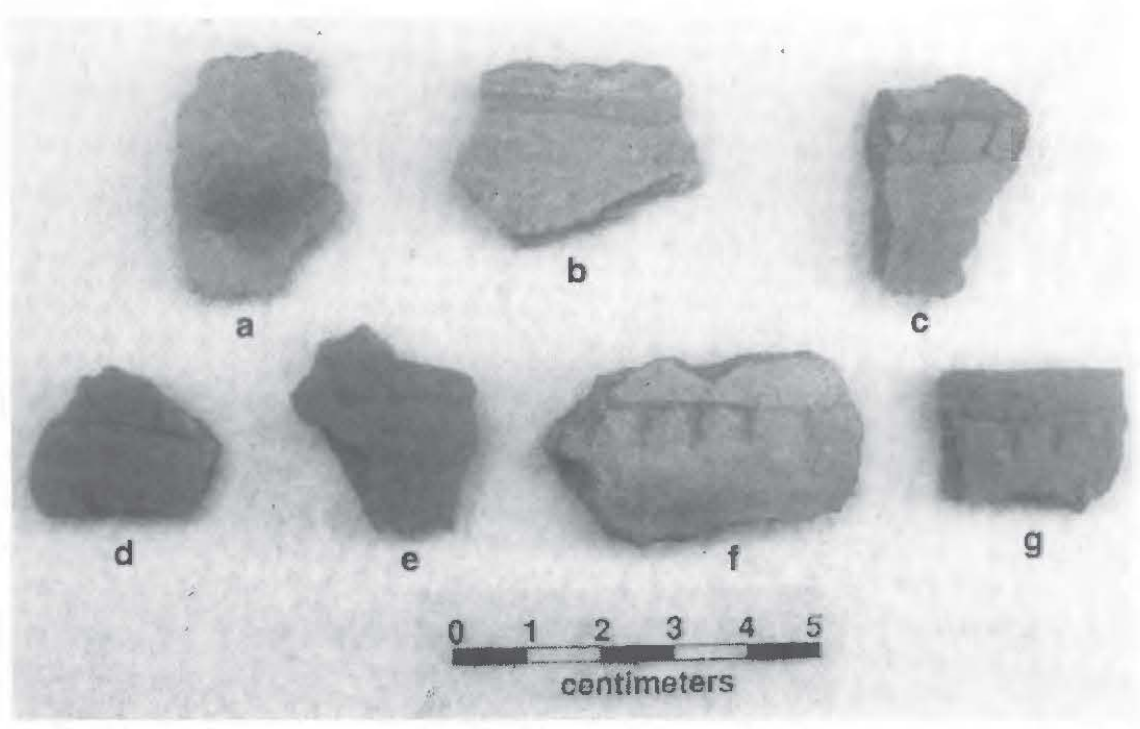

Figure 1. Engraved rim sherds from Patton Engraved, hatched engraved, horizontal engraved/lip notched, and engraved bottle sherd: $a$, engraved bottle sherd; $b$, horizontal engraved and lip notched; $c$, hatched; d-g, Patton Engraved. Provenience: a, Unit 4, 20-30 cm; b, Unit 4, 10-20 cm; c, FS 2, 10-20 cm; d, Unit 13, Fea. 2, 10-20 cm; e, Unit 11, 0-10 cm; f, Surface by Unit 13; g, surface. 


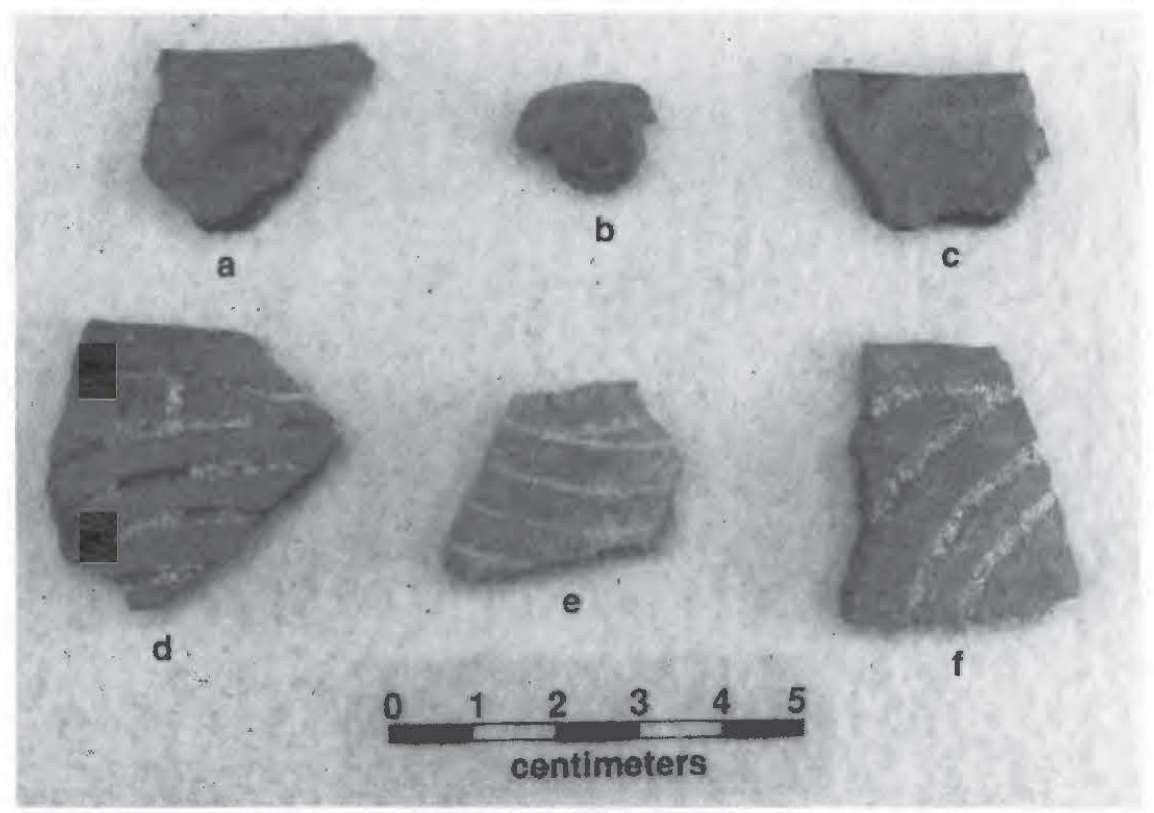

Figure 2. Poynor Engraved, Hume Engraved, and other engraved decorative elements on body sherds; a, c, Hume Engraved; b, circle element (cf. Patton Engraved); d, f, Poynor Engraved; e, multiple curvilinear engraved lines. Provenience: a, Unit 6, 40-50 cm; b, Unit 4, 10-20 cm; c, Unit 2, 10-20 cm; d, Unit 12, Fea. 2, 10-20 cm; e, Unit 9 , Fea. 2A, 15-20 cm; f, Unit 12,0-10 cm.

19), Hume Engraved vessels were made and used in the latter part of the Frankston phase and in the Allen phase, with the highest frequencies of Hume Engraved in Allen phase burials in the upper Neches River basin.

The three Poynor Engraved sherds (PP variety) are bowl rims (see Figure 2d, f). The two rims from the North area have a white pigment in the engraved lines. These particular sherds have a single broad horizontal engraved line on the rim that is connected to a series of either opposed or curvilinear engraved lines that would have extended across the rim surface. The PP variety of Poynor Engraved is found most frequently in late Frankston (ca. mid$16^{\text {th }}$ to mid-1 $7^{\text {th }}$ century) and Allen phase contexts (Kleinschmidt 1982:Table 19).

There are a few engraved bottle sherds in the fine wares (see Table 4). They account for 7.1-8.4\% of the engraved fine ware vessel sherds in the North and Alley areas, and another bottle sherd was recovered from the Southern area. The North and Southern area bottles have multiple sets of curvilinear lines on the vessel body (see Figure 2e), while the Alley area bottle sherd has an engraved zone filled with hatched lines (see Figure 1c). This particular bottle sherd may be from a Hume Engraved bottle (e.g., Suhm and Jelks 1962:Plate 42b, e; Kleinschmidt
1982:Figure 20).

The remainder of the engraved sherds mainly have unidentifiable decorative elements and motifs (see Table 4). They have simple sets of parallel or opposed engraved lines. A notable exception are the two lip-notched rims (see Figure $1 \mathrm{~b}$ ) from the Alley and North areas, possibly from Patton Engraved vessels, and the cross-hatched engraved body sherd (see Figure 1a) from the Alley area. Kleinschmidt (1982:Tables 4 and 5) notes that approximately $2 \%$ of the 581 engraved vessel batches at the Frankston phase A. C. Saunders mound site (41AN19) have lip notched rims: nine Poynor Engraved rims and four rims from unidentified engraved wares.

\section{Utility Wares}

The principal utility ware vessel sherds from the Kah-hah-ko-wha site have grass and frayed-stick brushing marks on them. The brushing typically covers both the rim and the vessel body, extending almost to the vessel base (Suhm and Jelks 1962:21 and Plate 11). These brushed vessel sherds are from Bullard Brushed jars (see Suhm and Jelks 1962; Kleinschmidt 1982).

The brushed rims have horizontal brushing marks $(n=8)$, vertical brushing $(n=2)$, diagonal 


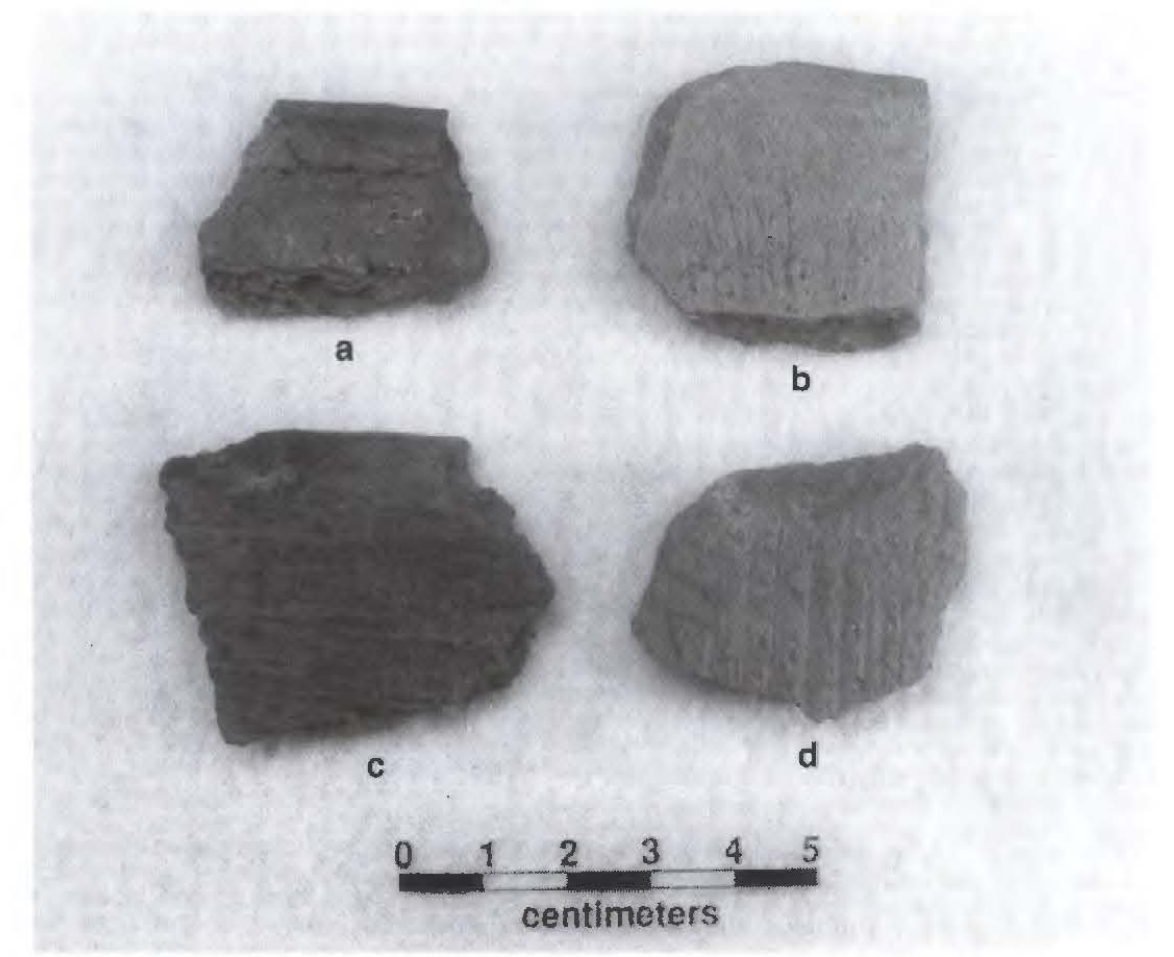

Figure 3. Brushed rim sherds and an opposed brushed body sherd: a, c, horizontal brushed; b, vertical brushed; d, opposed brushed body sherd. Provenience: a, Unit 7 , $30-40 \mathrm{~cm}$; b, Unit 1, 30-40 cm; c, Unit 15, 10-20 cm; d, Unit 13,0-10 cm.

brushing $(n=2)$, and one rim with opposed brushing marks (Figures 3 and 4). The diagonal and vertically brushed rims are found only in the Alley area, and the one opposed brushed rim is from the North area (Table 5). Horizontally brushed rims are present in both site areas.

The vessel bodies of the Bullard Brushed jars are usually vertically brushed (Suhm and Jelks 1962:21). It is likely that the many parallel brushed body sherds (Figure 5d; see also Figure 4d) of uncertain orientation in the vessel sherd assemblage (see Table 5) are actually vertically brushed parts of utility ware jars. Between 25.5-29.0\% of the jar bodies of these brushed vessels have opposed (see Figure 3d) or overlapping brushing marks (Figure 5a-c).

Less common decorative elements present on utility ware vessel sherds from the Kah-hah-kowha site are summarized in Table 6 . The brushedpunctated sherds (Figure 6a, d, f) are likely also from Bullard Brushed jars, as they are known to have rows of punctations below the lip and at the rim-body juncture (Suhm and Jelks 1962:Plate 21af; Kleinschmidt 1982:Figure 21). The punctations are usually pushed through the brushing marks, however, and this is generally the case in the Kah- hah-ko-wha decorated sherd assemblage. This is a more common decorative element in the Bullard Brushed vessel sherds from the North area.

Brushed-appliqued sherds include those with brushing marks paralleling either appliqued fillets or appliqued ridges. This form of utility ware decoration is well represented at the Deshazo site (Fields 1995:Figures 60g-h and Figure 62a-c), where the appliqued elements (including nodes) have been placed on either the rim or the body.

All three of the brushed-punctated-incised body sherds (Figure 7e; see also Figure 6e) are from the Alley area, as are the brushed-appliqued, appliqued, punctated, and neck banded utility ware sherds (Figure 7a-d). Although these decorated utility wares are not well represented at the site, the fact that they occur in only the Alley area is good evidence for the existence of different and changing utility ware stylistic traditions within the two Allen phase components at the site.

Incised rim and body sherds from Maydelle Incised vessels are particularly common in the North area, while brushed-incised body sherds are well represented in both areas. Elements represented in the incised sherds include horizontal, diagonal, 


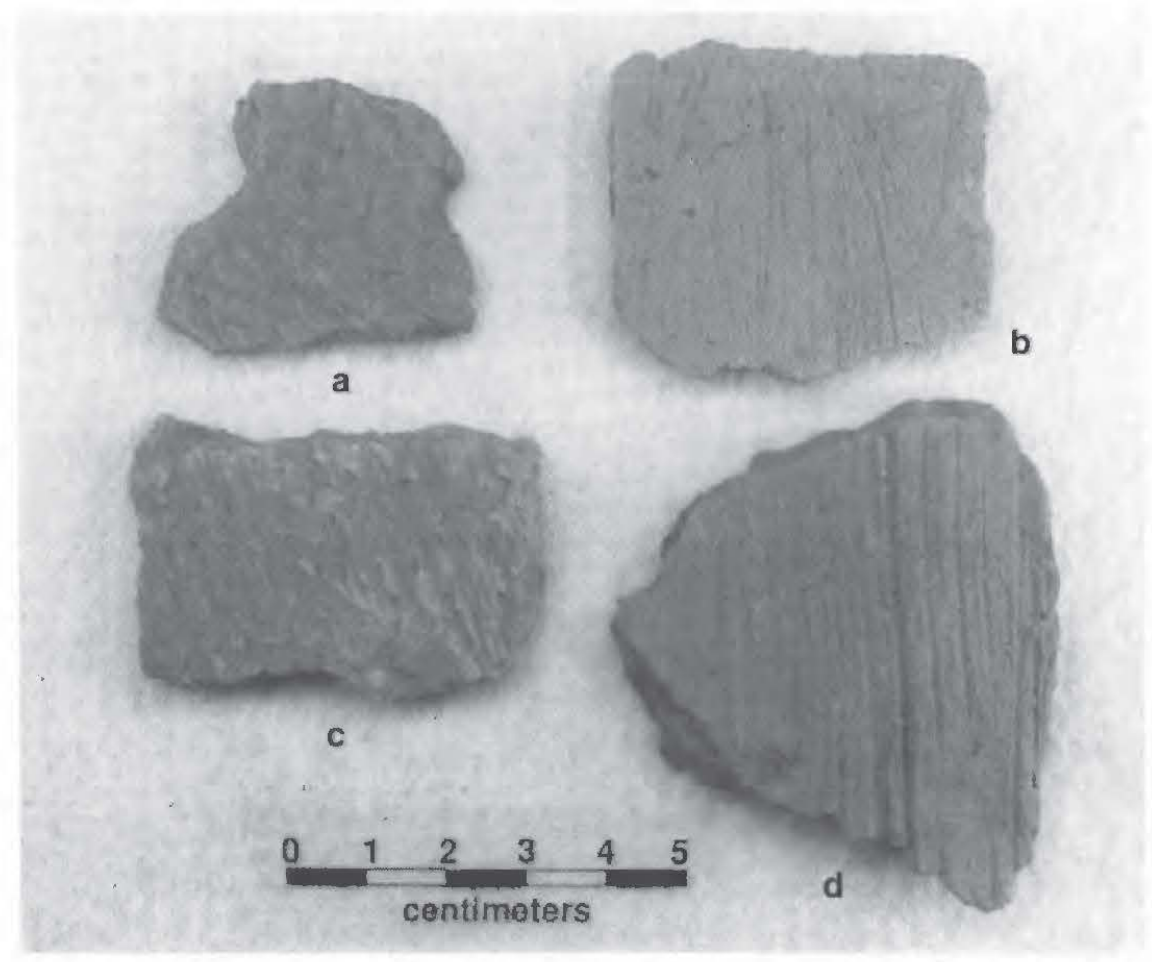

Figure 4. Overlapping brushed rim and body sherds and parallel brushed body sherd: a-c, overlapping brushed body sherds; d, parallel brushed body sherd. Provenience: a, Unit 9, 15-20 cm; b, ST 204, 0-20 cm; c, Unit 9, 10-20 cm; d, Unit 13, Fea. 2, 10-20 cm.

Table 5. Decorative elements in the brushed vessel sherds.

\begin{tabular}{lccc}
\hline $\begin{array}{l}\text { Decorative Class } \\
\text { and Element }\end{array}$ & Alley area & North area & Other \\
\hline Parallel brushed, body & $70.8^{*}$ & 66.3 & 81.0 \\
$\begin{array}{l}\text { Opposed brushed, body } \\
\text { Overlapping brushed, body }\end{array}$ & 2.3 & 1.9 & - \\
Overlapping brushed, rim & 23.2 & 27.1 & 19.0 \\
Horizontal brushed, rim & - & 0.9 & - \\
Diagonal brushed, rim & 1.8 & 3.7 & - \\
Vertical brushed, rim & 0.9 & - & - \\
\hline Totals & 0.9 & 107 & 21 \\
\hline
\end{tabular}

*percentage

cross-hatched, and opposed lines on the rim and bodies of vessels (see Figure $6 \mathrm{~b}-\mathrm{c}$ ), as well as one body sherd with widely-spaced curvilinear incised lines from the North area. Vessels that simply have punctations-usually in rows (see Figure 7d)-are present only in the Alley area, but rarely. Similarly, punctated sherds account for only $1.6 \%$ of the decorated sherds in the Allen phase component at the Deshazo site (Fields 1995:Figure 73a).

The brushed-punctated-incised body sherds are likely also from Maydelle Incised vessels, while the brushed-incised body sherds (Figure 8a-c) - that is, 


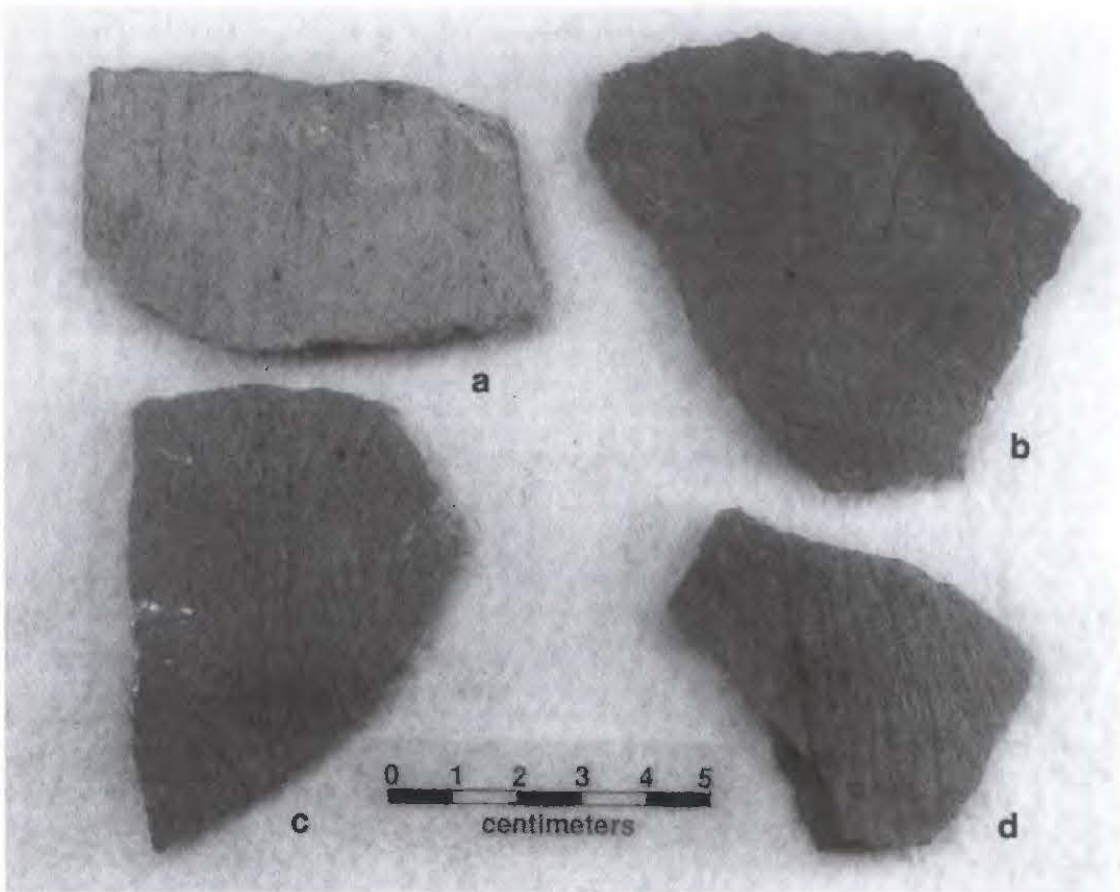

Figure 5. Parallel and overlapping brushed body sherds: a-c, overlapping brushed body sherd; d, parallel brushed body sherd. Provenience: a, FS 1, 20-30 cm; b, ST 224, 20-40 cm; c, Unit 4, 10-20 cm; d, MD 13, 0-20 cm.

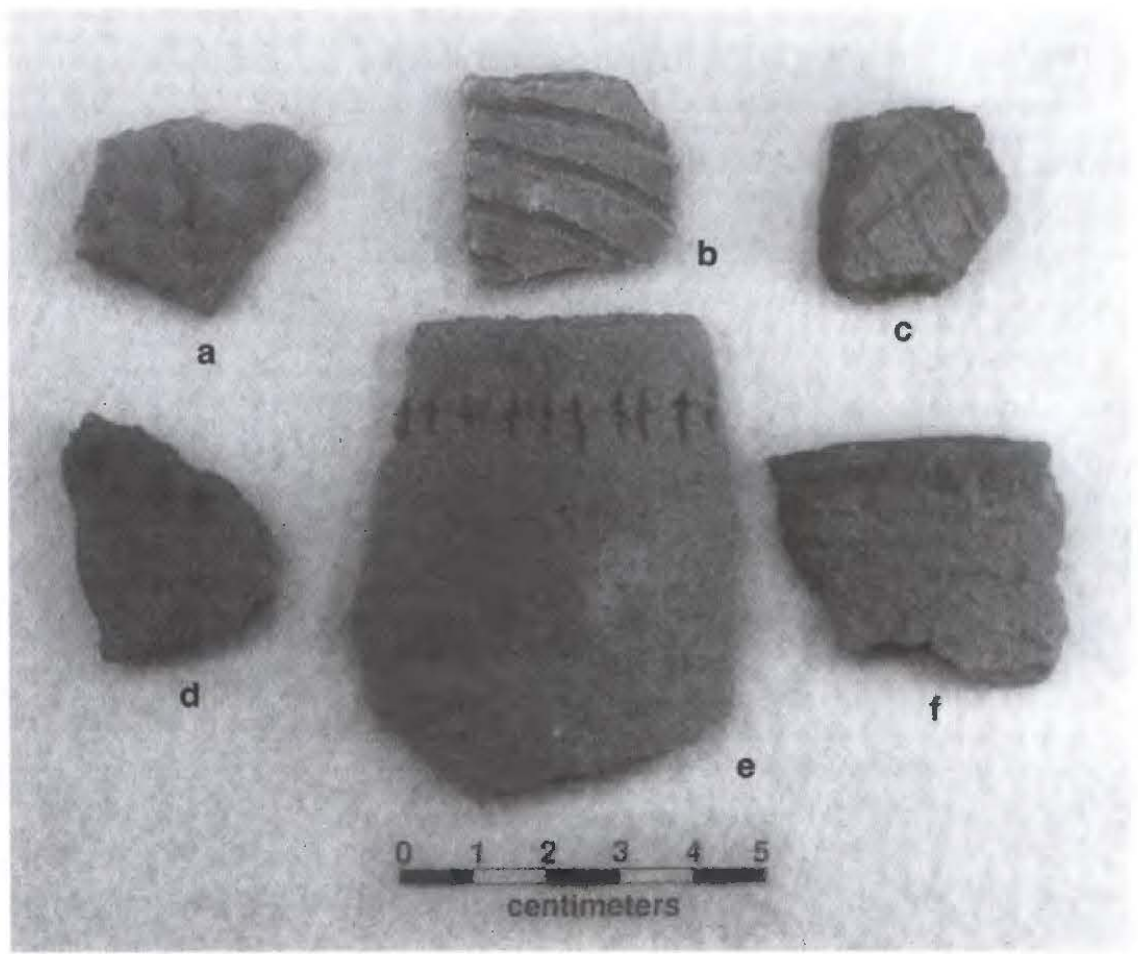

Figure 6. Brushed-punctated, brushed-punctated-incised, and incised sherds: a, d, f, brushed-punctated; b-c, incised sherds; e, brushed-punctated-incised sherd. Provenience: a, Unit 9, Fea. 2A, 10-15 cm; b, Unit 15, 20-30 cm; c, Unit 1, 10-20 cm; d, Unit 15, 30-40 cm; e, FS 2, 10-20 cm; f, Unit 6, 0-10 cm. 
Table 6. Decorative classes and elements for the other decorated utility ware sherds.

\begin{tabular}{llll}
\hline $\begin{array}{l}\text { Decorative Class } \\
\text { and Element }\end{array}$ & Alley area & North area & Other \\
\end{tabular}

\section{Brushed-Punctated}

Tool punctated row-

Horizontal-diagonal brushed, body

Tool punctated row-horizontal

Brushed, rim

Tool punctated row-horizontal

Brushed, body

Tool punctations through

parallel brushing, body

Tool punctations through

overlapping brushed, body

Tool punctations adjacent

to parallel brushed

\section{Brushed-Punctated-Incised}

Diagonal incised-tool

punctated row-horizontal

brushed, body

Horizontal brushed-linear

Punctated-overlapping

brushed, body

\section{Brushed-Appliqued}

Parallel brushed-appliqued

fillet, body

Parallel brushed-parallel

appliqued ridge, body

\section{Brushed-Incised}

Parallel brushed-incised, body

Opposed-parallel brushed-

Incised, body

Overlapping brushed-

Incised, body

Opposed brushed-incised, body

Horizontal incised-vertical

Brushed, body

\section{Brushed-Punctated-Appliqued}

Parallel brushed-appliqued

Ridge-tool punctated row, body

2.6

2.6

5.3

2.6

26.3

$-$

7.9

2.6

$-$

$\begin{array}{ll}- & 3.7^{*}\end{array}$

11.1

3.7

3.7

11.1

25.0

11.1

11.1

25.0

3.7

3.7 
Table 6. (Continued)

\begin{tabular}{|c|c|c|c|}
\hline $\begin{array}{l}\text { Decorative Class } \\
\text { and Element }\end{array}$ & Alley area & North area & Other \\
\hline \multicolumn{4}{|l|}{ Incised } \\
\hline $\begin{array}{l}\text { Parallel and cross-hatched } \\
\text { Incised, body }\end{array}$ & - & 3.7 & - \\
\hline Parallel incised, body & 13.2 & 7.4 & - \\
\hline $\begin{array}{l}\text { Opposed incised, widely- } \\
\text { spaced, body }\end{array}$ & - & 3.7 & - \\
\hline Opposed incised, body & 2.6 & 7.4 & \\
\hline Curvilinear incised, body & - & 3.7 & - \\
\hline Straight incised line, body & - & 3.7 & - \\
\hline Diagonal incised, rim & 2.6 & - & - \\
\hline Cross-hatched incised, rim & 2.6 & 3.7 & - \\
\hline Horizontal incised, rim & - & 3.7 & - \\
\hline \multicolumn{4}{|l|}{$\Lambda$ ppliqued } \\
\hline Appliqued node cluster. body & 2.6 & - & - \\
\hline P'arallel appliqued ridges, body & 7.9 & - & - \\
\hline large appliqued node, rim & 2.6 & & - \\
\hline \multicolumn{4}{|l|}{ Punctated } \\
\hline Tool punctated, rim & 2.6 & - & - \\
\hline Tool punctated row, body & 2.6 & - & $25.0+$ \\
\hline \multicolumn{4}{|l|}{ Neck Banded-Brushed } \\
\hline $\begin{array}{l}\text { Neck handed and vertical } \\
\text { Brushed, body }\end{array}$ & - & - & $25.0^{* * *}$ \\
\hline Totals & 38 & 27 & 4 \\
\hline
\end{tabular}

*percentage, ${ }^{* *}$ from a shovel test in the Alley arca, +from the Southern arca

sherds decorated with marks from bundles of grass crossed or paralleled by various incised lines-are from Bullard Brushed vessels (see Kleinschmidt 1982:Figure 21). Fields (1995:180 and Figure 66a-c) does identify Karnack Brushed-Incised sherds from the Allen phase component at the Deshazo site, but those vessel sherds had parallel incised lines over roughened surfaces, not over well-defined brushing marks as at the Kah-hah-ko-wha site.

Rim sherds are present only in the appliqued, punctated, and incised decorative classes (see Table 6). The other utility ware sherds listed in Table 6 represent the range of decorative elements to be found only on the vessel body of jars. The one neck banded and brushed body sherd is from a LaRue Neck Banded jar with vertical brushing on the vessel body. The rarity of neck banded pottery in Allen phase contexts is apparent from the fact that only seven of the 23,651 decorated sherds from the Deshazo site have neck banding (Fields 1995:Figure $75 \mathrm{f}-\mathrm{g}$ ). Appliqued sherds at the Kah-hah-ko-wha site (see Figure $7 \mathrm{a}-\mathrm{c}$ ) represent $1.1 \%$ of all the decorated sherds, which is slightly more than the relative proportions of appliqued sherds at Deshazo $(0.4 \%)$. Fillets and nodes can occur on both the rim or the body of utility ware jars. 


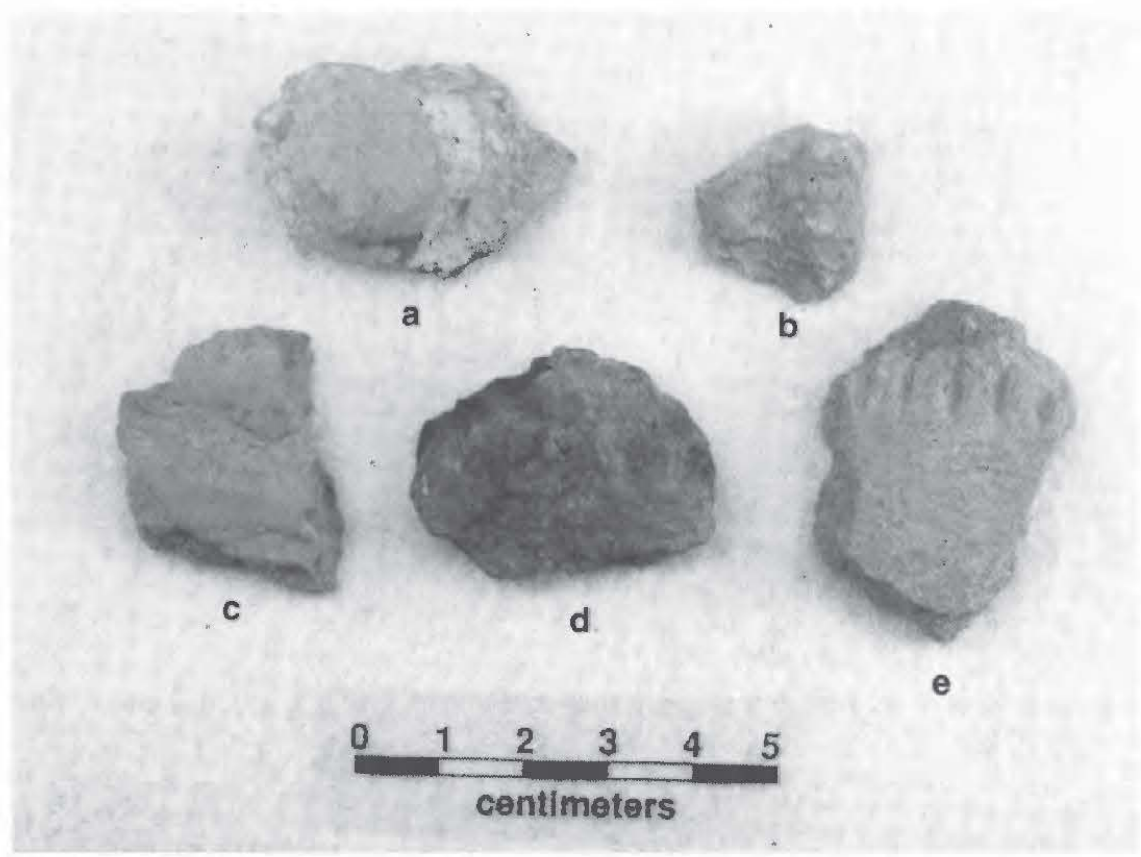

Figure 7. Tool punctated, appliqued, and brushed-punctated-incised utility ware sherds: a-c, appliqued; d, punctated; e, brushed-punctated-incised. Provenience: a, Unit 2, 10-20 cm; b, Unit 3, 30-40 cm; c, Unit 7, 20-30 cm; d, Unit 6, 30-40 cm; e, Unit 7, $20-30 \mathrm{~cm}$.

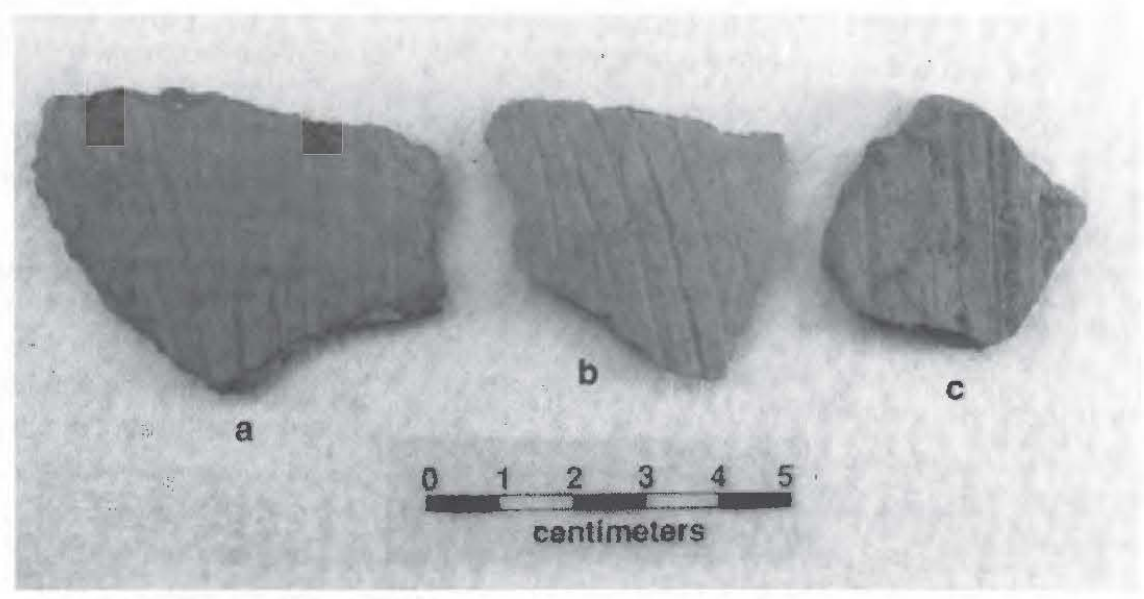

Figure 8. Brushed-incised sherds. Provenience: a, Surface by Unit 13; b, Unit 18, 0-10 $\mathrm{cm}$; c, Unit 13, 10-20 cm.

\section{Plain Wares}

The plain ware vessel sherds include seven rims and 87 body and base sherds. Proportionally, plain ware vessel sherds are more abundant in the North area than the Alley area, as they comprise $24 \%$ of all the sherds in the former area and only $11.7 \%$ in the latter area. Six of the seven plain rims, apparently from medium-sized bowls, are also from the North area (Figure 9).

\section{ORIFICE DIAMETERS AND RIM FORMS}

Of the 36 rims in the collection from the site, vessel orifice diameter (OD) could be measured on only nine of them: three plain ware bowl rims, three utility ware jar rims, and three fine ware rim sherds. In the plain wares, the OD ranges from $15-17 \mathrm{~cm}$, compared to $16-19 \mathrm{~cm}$ in the utility wares; one utility ware rim had an OD greater than $19 \mathrm{~cm}$. These 


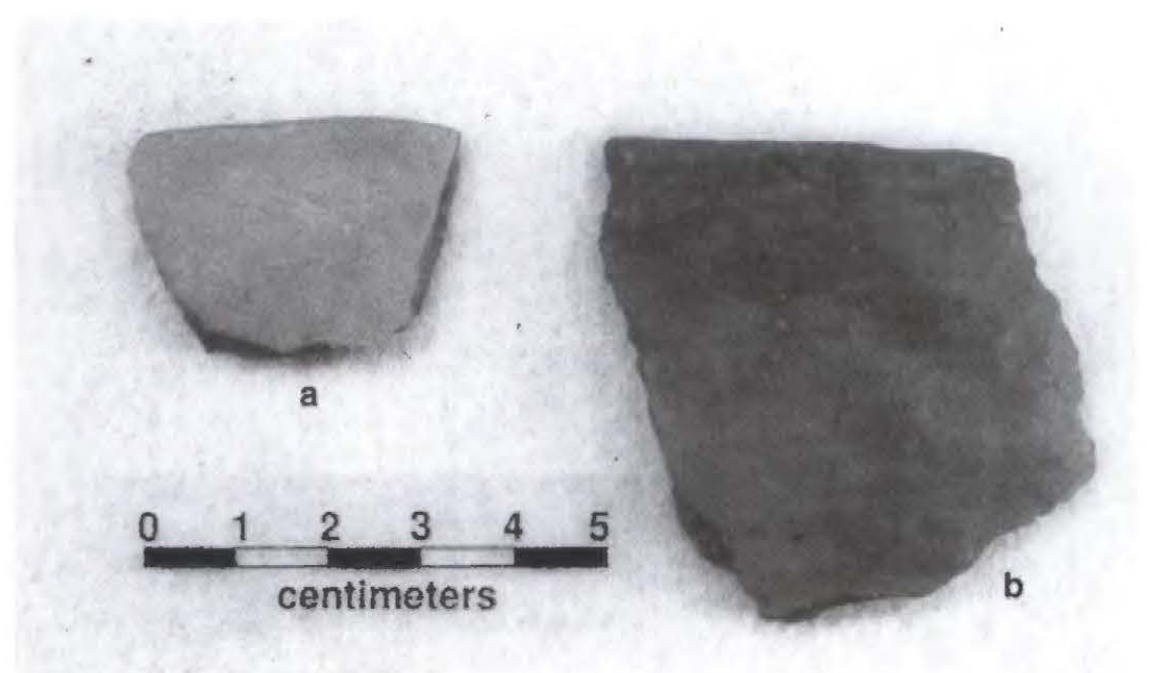

Figure 9. Plain ware rims from the North area. Provenience: a, Unit $20,7 \mathrm{~cm}$; b, Unit $10,10-20 \mathrm{~cm}$.

are medium-sized vessels. The fine ware rims (from carinated bowls) are from larger vessels, as the OD values are $16.0 \mathrm{~cm}, 22.0-24.0 \mathrm{~cm}$, and a third rim with an OD greater than $21.0 \mathrm{~cm}$.

Rim and lip forms vary by vessel ware category (Table 7). Most of the vessels have a direct or standing rim (e.g., Brown 1996:Figure 2-12), but everted rim jars are also well represented in the utility wares. Inverted rim bowls and carinated bowls are only present in the plain wares and fine wares, one plain ware vessel from the Alley area and two carinated bowls in the North area.

Vessel lips tend to be rounded among all three wares, although flat lips are particularly well represented in the plain wares ( $43 \%$ of the rims) (see Table 7). Exterior folded lips occur only in the utility wares; furthermore, this distinctive lip treatment is present only among the Alley area utility wares.

\section{WARE COMPARISONS OF TEMPER, FIRING CONDITIONS, SURFACE TREATMENT, AND WALL THICKNESS}

Certain technological attributes of the ceramic vessel sherds from the North and Alley areas at the Kah-hah-ko-wha site can be compared to determine if there are differences in how the vessels were made, fired, and used across the site. The ceramic attribute data reviewed below is based on detailed decorated $(n=168$ sherds) and plain sherd $(n=59)$ analyses (Perttula and Nelson 2007:Appendix 5).
Johnson (1992:18) provides a succinct summary of the reconstructed manufacturing process of Caddo vessels that is certainly applicable to the ceramic vessels and vessel sherds recovered from the Kahhah-ko-wha site:

Caddo pottery... represents an ancient tradition of vessel making that pretty much had all the bugs worked out of it. Even vessels that show poor artisanship exhibit good "engineering": During the rough stages of work, potters thinned vessels on the inside by scraping them with gourd pieces or other sizeable but thin objects, and then evened up the surfaces by rubbing them, apparently with a stone. Finally, they smoothed the vessels with bundles of grass, pieces of hide, or wet brushes that were not too coarse. In their shaping of vessels, Caddo potters certainly did not mess about with the flat end of sticks... or with bunches of sharp twigs. Furthermore, the rims of most Caddo vessels (except for sharp-rimmed bottles) were made thick enough to stand up under ladle banging, and I have seen no evidence of sloppily repaired greenware cracks or greenware rim peeling. In fact, Caddo potters habitually made an effort to eradicate coil joins and tool marks except inside some narrow-mouthed jars and bottles... All these thinning and smoothing techniques are advanced and quite satisfactory. 
Table 7. Rim and Lip forms.

\begin{tabular}{lccccccc}
\hline Ware & \multicolumn{3}{c}{ Rim Form } & & \multicolumn{3}{c}{ Lip Form } \\
& $D^{*}$ & EV & INV & RO & FL & RO, ext f & FL, ext f \\
\hline Plain Ware & 5 & 1 & 1 & 4 & 3 & - & - \\
Utility Ware & 8 & 7 & - & 11 & 2 & 2 & 1 \\
Fine Ware & 9 & - & 2 & 9 & 2 & - & - \\
Totals & 22 & 8 & 3 & 24 & 7 & 2 & 1 \\
\hline
\end{tabular}

$* \mathrm{D}=$ direct or vertical; $\mathrm{EV}=$ everted; $\mathrm{INV}=$ inverted; $\mathrm{RO}=$ rounded; $\mathrm{FL}=$ flat; ext $\mathrm{f}=$ exterior folded

The Allen phase vessel sherds from the Kahhah-ko-wha site are from vessels that are tempered almost exclusively with grog (fired clay and/or crushed sherds). Between $97.1 \%$ and $98.4 \%$ of the sampled sherds from the North and Alley areas, respectively, have grog temper inclusions (Table 8 ). The few sherds that do not have a grog temper either have crushed and burned bone $(1.6 \%$ of the sherds from the Alley area) or have no temper and a sandy paste $(2.9 \%$ of the sherds from the North area). Other temper inclusions found in the paste of the vessel sherds are hematite and charred organic remains (i.e., visible pieces of charcoal), but these occur exclusively in association with grog temper.

The variability in temper-paste use in the Kahhah-ko-wha site ceramics is much lower than that seen in earlier Caddo sites in the region (i.e., only eight temper-paste combinations here, compared to 31 temper-paste combinations at a ca. A.D. 1150-1430 site reported by Perttula and Nelson [2003], for example). It is fair to conclude that the Kah-hah-ko-wha ceramics are a product of a ceramic vessel making tradition that was quite standardized in manufacturing and vessel engineering, and "pretty much had all the bugs worked out of it" (Johnson 1992:18). The heavy use of grog temper in this ceramic assemblage is completely consistent with other upper Neches River basin Caddo sites (see Table 1), where grog tempered sherds comprise more than $90 \%$ of all the sherds from Caddo occupations dating after ca. A.D. 1250.

The very high frequency of grog-tempered pottery at the site is believed to represent a specific

Tabie 8. Temper classes by ceramic ware.

\begin{tabular}{|c|c|c|c|c|c|c|}
\hline \multirow[t]{2}{*}{ Temper and Paste Class } & \multicolumn{3}{|c|}{ Alley area } & \multicolumn{3}{|c|}{ North area } \\
\hline & $\mathrm{FW}^{*}$ & UW & PW & FW & UW & PW \\
\hline Grog & $90.0+$ & 75.0 & 44.0 & 73.3 & 63.6 & 67.6 \\
\hline Grog-hematite & 0.0 & 11.4 & 12.0 & 6.7 & 23.6 & 8.8 \\
\hline Grog/sandy paste & 0.0 & 10.2 & 28.0 & 13.3 & 10.9 & 11.8 \\
\hline Grog-hematite/sandy paste & 0.0 & 1.1 & 4.0 & 0.0 & 0.0 & 0.0 \\
\hline Grog-organics & 0.0 & 0.0 & 4.0 & 0.0 & 0.0 & 0.0 \\
\hline Bone-grog & 10.0 & 1.1 & 8.0 & 6.7 & 0.0 & 2.9 \\
\hline Bone & 0.0 & 2.3 & 0.0 & 0.0 & 0.0 & 0.0 \\
\hline Sandy paste & 0.0 & 0.0 & 0.0 & 0.0 & 0.0 & 8.8 \\
\hline Totals & 10 & 88 & 25 & 15 & 55 & 34 \\
\hline
\end{tabular}

*FW= fine ware; $\mathrm{UW}=$ utility ware; $\mathrm{PW}=$ plain ware +percentage 
attempt on the part of the Caddo potters to slow the oxidation process of the ceramic vessels during firing. This would have created darker-colored vessels in the reducing environment (or lighter tan, orange, and brown colors in oxidizing environments), while allowing them to be fired longer, and producing a harder ceramic vessel (Rice 1987:354; Teltser 1993:532, 540). Since grog has expansion coefficients comparable to the coefficients of the clay paste - especially with the finely crushed grog pieces as seen in the finc wares-this would have further contributed to the ability of fired vessels to withstand heat-related stresses, as wcll as increasing their flexural strength (Rice 1987:362).

Between $12.5-14.6 \%$ of the sherds from the Kah-hah-ko-wha site have a sandy paste (see Table 8 ). This suggests the frequent use of a sandy clay for vessel manufacture. The highest proportions of sandy paste sherds are in the plain wares $(20.3 \%)$. with lesser amounts among the utility wares $(11.3 \%)$ and the fine wares $(8.0 \%)$. The plain wares-along with the utility wares from the North and Alley areas-also have the highest proportions of crushed hematite and bone-tempered sherds in the assemblage (see Table 8). It is probable that the Caddo potters recognized that sandy clays held up better to heat-related stresses and helped with vessel porosity and thermal conductivity, which would have had practical value given the repeated use of utility ware vessels for the cooking of foods and the serving of foods and liquids in simple bowls (see Rice 1987, 1996). The relatively high amount of quartz sand in the paste of certain utility ware and plain ware vessels may be related to decisions made by Caddo potters to be able to better control the making and firing of harder and more durable vessels.

The use of hematite as a temper may have served the same purpose as feldspars, which are often found together in the paste of Caddo vessels. The occurrence of fine grains of these minerals in the paste would have enhanced a vessel's ability to melt and fuse the paste constituents during firing, resulting in a dense, hard body, and a reduced vessel porosity (Rice 1987:96).

There are differences in the use of tempers between the fine wares, utility wares, and plain wares, with the highest proportional use of grog in the fine wares (see Table 8), and the lowest among the plain ware vessels. The use of crushed pieces of hematite as temper is more common in the utility and plain wares, especially the utility wares in the North area, and only $4 \%$ of the fine wares from both the North and Alley areas have hematite tempering. Bone tempering occurs in low frequencies in all three ware categories. Coarse sandy paste sherds in the Alley area are found only in the utility wares and plain wares, but is equally prevalent in all three wares in the North arca. The two sherds with preserved organic remains in the paste are only in the utility wares and plain wares, one sherd each from both site areas (see Table 8). The sherds from these particular vessels indicate that a certain small proportion of vessels were not fired at high temperatures and/or not fired for a long duration. Accordingly, the organic materials naturally present in the worked clay did not have a chance to be completely burned off during firing.

In addition to these differences in temper between the different wares, therc arc also subtle differences in temper-paste composition between the ceramic vessel sherds in the Alley arca and vessel sherds in the North area (see Table 8). These are summarized below:

- Vesscls tempered only with grog temper are 11-17\% more common among the utility ware and fine wares in the Alley area, while plain wares are much more likely (23\% more likely) to be grog-tempered in the North area;

- Vessel sherds with hematite temper inclusions are more abundant in the North area, especially among the utility wares:

- Bone-tempered vessel sherds are twice as common in the Alley area than in the North area. even though the absolute frequency of bone tempering is low in both areas:

- Plain wares with sandy paste sherds are a good hit more plentiful $(32 \%)$ in the Alley area than they are in the North area (20.6\%), and the overall use of sandy paste sherds is more common in the Alley area.

The Caddo potters at the Kah-hah-ko-wha site fired their vessels in a number of different ways. Most of the fine wares and plain wares were fired in a reducing or low oxygen environment-probably smothered in a bed of coals from a wood fire-as 60$80 \%$ of the fine wares and $60-79 \%$ of the plain wares were fired this way (Table 9). Most of them were subsequently cooled in a high oxygen environment, probably meaning that the fire-hardened vessel was removed from the fire to cool. A significant number 
Table 9. Firing conditions of the ceramic sherds.

\begin{tabular}{|c|c|c|c|c|c|c|}
\hline \multirow[t]{2}{*}{ Firing Conditions* } & \multicolumn{3}{|c|}{ Alley area } & \multicolumn{3}{|c|}{ North area } \\
\hline & $\mathrm{FW}^{* *}$ & UW & PW & FW & UW & PW \\
\hline A (oxidizing environment) & $30.0+$ & 45.6 & 16.0 & 13.3 & 18.2 & 11.8 \\
\hline B (reducing environment) & 0.0 & 5.6 & 12.0 & 40.0 & 16.4 & 29.4 \\
\hline C-E (incompletely oxidized & 10.0 & 17.8 & 16.0 & 6.7 & 14.5 & 5.9 \\
\hline I-L during firing) & 0.0 & 6.6 & 4.0 & 0.0 & 12.6 & 5.9 \\
\hline $\begin{array}{l}\text { F-H (reducing environment, } \\
\text { cooled in the open air) }\end{array}$ & 60.0 & 23.3 & 48.0 & 40.0 & 38.2 & 50.0 \\
\hline $\begin{array}{l}\text { X (possibly refired, } \\
\text { smudged, sooted) }\end{array}$ & 0.0 & 1.1 & 0.0 & 0.0 & 0.0 & 0.0 \\
\hline
\end{tabular}

${ }^{*}$ Categories are based on Teltser (1993: Figure 2) and Perttula (2005:Figure 5-30)

**FW= fine ware; $\mathrm{UW}=$ utility ware $\mathrm{PW}=$ plain ware

$+=$ percentage

of the vessel sherds, however, were allowed to cool in the firc, where they kept their dark surface colors, aud this is especially the case in the North area among the fine wares, plain wares, and utility warcs.

More of the utility ware vessels were fired in a high oxygen environment than is the case for the fine wares or plain wares (see Table 9). More than $70 \%$ of the utility ware sherds from the Alley area and $45 \%$ of the North area vessel sherds were from vessels fired in this manner. A number of these utility warc vessel sherds are from vessels that were incompletely oxidized during firing, occurring at rates two to four times higher than in the fine wares.

There are significant differences in how utility ware, plain ware, and fine ware vessels were fired at the site, further differentiating these basic vessel classes. The comparison of sherd firing conditions suggests that the fine ware and plain ware vessel sherds were better made and better fired (at least in terms of regulating the firing temperature), and probably fired longer in a low oxygen environment, than the utility ware sherds. The Caddo potters exerted more control over the end product of fine ware and plain ware vessel manufacture than they did with the utility wares, primarily to produce a harder ceramic. The more heterogeneous firing conditions of the utility wares-particularly the many incompletely oxidized vessel sherds-is likely the result of the multi-purpose nature of these vessel forms, as they were used as cooking pots and storage containers. As long as the porosity of the utility wares was nol excessive, they did not need to be fired for as long a time as the hardcr finc warcs to be quite serviceable and without being subject to diminished strength from cumulative thermal fatigue as wcll as cracks and lractures.

Many of the vessel sherds from the Kah-hahko-wha site retain evidence of the smoothing or burnishing of interior and/or exterior surfaces (Table 10). These surface treatments were done to thin and even out the vessel surfaces, strengthen them by melding coil joins, and even to create a surface appearance that enhanced the vessel decoration.

Among the utility ware sherds from both areas of the site, most of them (between $65-71 \%$ ) have been smoothed on the interior surface, while less than $10 \%$ have been smoothed or burnished on exterior surfaces. This smoothing was most likely consistently done to lower the permeability and increase the heating effectiveness of particular vessels (cf. Rice 1996:148), that being the utility ware vessels used for cooking.

The decorated fine ware sherds are more frequently smoothed on the exterior surface than the utility wares (20-40\% compared to less than $2 \%$ ) as well as more commonly burnished on either interior (20-40.0\%) or exterior (46.7-60.0\%) vessel surfaces. None of the utility ware vessels are burnished on 
Table 10. Surface treatment on vessel sherds.

\begin{tabular}{lcc}
\hline Surface Treatment & Alley area & North area \\
\hline Fine ware & & \\
Interior smoothed & $20.0^{*}$ & 46.7 \\
Exterior smoothed & 20.0 & 40.0 \\
Interior burnished & 40.0 & 20.0 \\
Exterior burnished & 60.0 & 46.7 \\
& & \\
Utility ware & & \\
Interior smoothed & 64.8 & 70.9 \\
Exterior smoothed & 0.0 & 1.8 \\
Interior burnished & 10.2 & 3.6 \\
Exterior burnished & 0.0 & 0.0 \\
& & \\
Plain ware & & 32.4 \\
Interior smoothed & 32.0 & 26.5 \\
Exterior smoothed & 40.0 & 20.6 \\
Interior burnished & 4.0 & 23.5 \\
Exterior burnished & 12.0 & \\
*percentage & &
\end{tabular}

exterior vessel surfaces. North area fine wares are more likely to have smoothed surfaces than the Alley ceramics ( $43 \%$ versus $30 \%$ ) while the Alley area fine wares tend to be more commonly burnished (50\% versus $33 \%$ in the North area).

The comparable smoothing and burnishing of interior and exterior vessel surfaces of the fine wares (not including the bottles, which have a roughened interior vessel body) indicates that the fine warcs were not used for cooking purposes, but probably to serve and hold foods and liquids. The smoothed and burnished $(60-67 \%$ of all the fine ware sherds) surfaces of such vessels would have been advantageous in the repeated use of such serving vessels. The exterior smoothing and burnishing, beyond its purpose in melding coil joins, was probably designed to have stylistic and display purposes, creating a flat and lustrous surface well-suited to highlight the engraved and/or slipped exterior surfaces of the fine ware vessels.

The plain ware sherds are more like the fine wares than the utility wares with respect to vessel wall surface treatments (see Tablc 10). Smoothing of vessel surfaces is equally common on both the interior (32\%) and exterior (26-40\%) walls of vessels in both site areas-as it is with the fine wares-and burnished vessel surfaces are much more common in the plain wares (both interior and exterior surfaces) than they are in the utility wares. This surface treatment information suggests that most of the plain wares were used more like fine wares than utility wares, being well-smoothed and burnished, and probably were made to also be used in the serving of foods and liquids.

The decorated utility ware vessel sherds from both arcas at the Kah-hah-ko-wha site have thicker rim and body walls than do the fine ware vessel sherds as well as the plain ware vessel sherds (Table 11). This is to be expected becausc the utility warc vessels were made to stand up to repeated heating and cooling-and the thicker walls would help lessen heat-related stresses and wall cracking-as well as to have qualities that contributed to better vessel porosity and thermal conductivity during cooking use. The thicker rims on the utility warc vessels $(30-40 \%$ thicker than the fine ware vessel rims) would have been well-suited to repeated handling and lifting, and in their resistance to breakage and fracturing from serving and stirring utensils.

The North area utility ware vessel sherds are significantly thicker than the Alley area utility wares (see Table lI). It is not clear why there is this 
Table 11. Mean thickness (in mm) of vessel sherds.

\begin{tabular}{lccccccc}
\hline \multirow{2}{*}{ Area } & \multicolumn{2}{c}{ Fine wares } & \multicolumn{2}{c}{ Utility wares } & \multicolumn{3}{c}{ Plain wares } \\
& Rim & Body & Rim & Body & Rim & Body & Base \\
\hline Alley & 6.58 & 6.38 & 8.36 & 8.69 & 7.30 & 7.0 & 11.26 \\
North & 6.70 & 6.31 & 9.30 & 9.03 & 6.22 & 7.1 & 11.24 \\
\hline
\end{tabular}

considerable difference in wall thickness between these two Caddo occupations, but it is another piece in the growing appreciation of the existence of diverse intra-site activities at the Kah-hah-ko-wha site. These thickness differences may be related to the manufacture of larger (and hence thicker-walled) utility ware jars for cooking and storage tasks in the North area when compared to those in use in the Alley area, as well as to basic differences in the use and use-life of these durable vessels. This could include greater storage needs in one area when compared to another and more sustained household cooking requirements-leading to a reliance on larger vessels-and even to differences in the kinds and amounts ol clays that were available for vessel manufacture.

Fine ware vessel sherds are well-fired, with hard and durable vessel walls that are quite thin among the broken vessels in both the North and Alley areas (see Table 11). Rim and body wall thickness are equivalent, since there was less need to have a thicker and sturdy rim as well as thick body walls that could handle prolonged use (as there would be in the utility wares) because the fine ware vessels were designed as serving ware and to hold liquids, not for use in daily cooking activities. Plain ware vessels from both areas also have relatively thin rim and body walls (see Table 11), little different from the fine wares, but thick bases that would have lent stability to the plain ware bowls while they were in use.

\section{SUMMARY OF THE CERAMIC VESSEL SHERD ASSEMBLAGE}

The Caddo ceramic assemblage from the Kah-hah-ko-wha site appears to represent a single Allen phase component with stylistic affiliations to ca. A.D. 1650-1720 Caddo sites in the upper Neches and Angelina River basins. It represents a non-mortuary Allen phase component, and as such, provides a unique view of the character of the ceramic assemblage in an early historic upper Neches River Caddo domestic context.

The assemblage is dominated by medium-sized vessels with brushed decorations on utility ware vessel sherds, as well as a few incised, brushedincised, and brushed-punctated jars, engraved fine wares (carinated bowls and bottles, a few of which have a white pigment worked into the design), the heavy use of grog-tempered ceramic pastes, and the common reduced or low oxygen firing of both utility, plain, and fine wares. There are clear differences in both the North and Alley areas in temper and paste attributes, firing conditions, surface treatment, and vessel wall thickness - as well as the kinds of decorations placed on vessel rims and body surfaces of the fine wares, utility wares, and plain wares. These differences can be readily traced to diverse technological, functional, stylistic, and idiosyncratic decisions and strategies (cf. Johnson 1992:16-18) made by Caddo potters from different family or kin groups (e.g., LaVere 1998:92) on how to shape, fire, finish, and decorate ceramic vessels that were used in domestic tasks here. Similar kinds of vessels were also used for ritual and ceremonial activities at community cemeteries and certain family cemeteries.

There are stylistic and technological differences in the ceramic vessel sherds between the North area and the Alley area. These differences may simply represent functional and intra-site differences between two households in a contemporaneous Allen phase community, hinting that some of the Caddo social elite might have been living in one area of the site. Another possibility is that the North and Alley areas were not occupied at the same time by Allen phase families, but the few available radiocarbon dates obtained from the Kah-hah-ko-wha site do not support this contention. If this were shown to be the case following more extensive radiocarbon dating efforts at the site, it does not seem likely 
that much time separates the occupations in the two areas because the same principal ceramic types (i.e., Patton Engraved, Poynor Engraved, and Bullard Brushed) are present in both areas. If temporal factors are the primary reason that accounts for the subtle differences in the manufacture, firing, and decoration of ceramic vessels used in both areas, then the Kah-hah-ko-wha ceramic assemblage provides solid evidence for generational changes in Caddo vessel craftsmanship.

Archaeological and ethnographic information on the accumulation of pottery sherds (especially utility ware sherds or cooking-pot sherds) in domestic contexts suggest that $4000-8000$ grams of cooking pot sherds would be accumulated through breakage and use per year on a residential site occupied by Native American farmers (see Varien 1999: Table 4.2). We estimate that there are approximately 10,000 grams (1110-1180 sherds, weighing on average 8-9 grams each) of sherds in the North and Alley area principal ceramic concentrations.

Approximately $90 \%$ of the sherds ( 9,000 grams) are from utility ware sherds, based on the proportion of utility ware to fine ware sherds in the overall site ceramic assemblage. This suggests that the utility ware sherds at the Kah-hah-ko-wha site could have been accumulated in toto in only about 1-2 years of occupation by Caddo families living in the North and Alley areas. Since Caddo wood structures would probably only have lasted at most 20 or so years before they began to deteriorate (see Good 1982:69), this ceramic accumulation evidence further suggests that the Kah-hah-ko-wha site was occupied for only a very short time by Caddo peoples and then rather quickly abandoned.

\section{REFERENCES CITED}

Anderson, K. M., K. Gilmore, O. R. McCormick, III, and E. P. Morenon

1974 Archaeological Investigations at Lake Palestine, Texas. Contributions in Anthropology No. 11. Department of Anthropology, Southern Methodist University, Dallas.

Brown, J. A.

1996 The Spiro Ceremonial Center: The Archaeology of Arkansas Valley Caddoan Culture in Eastern Oklahoma. 2 Vols. Memoirs No. 29. Museum of Anthropology, University of Michigan, Ann Arbor.
Cole, N. M.

1975 Early Historic Caddoan Mortuary Practices in the Upper Neches Drainage, East Texas. Master's thesis, Department of Anthropology, The University of Texas at Austin.

Fields, R. C.

1995 Analysis of Native-Made Ceramics. In The Deshazo Site, Nacogdoches County, Texas, Volume 2: Artifacts of Native Manufacture, edited by D. A. Story, pp. 173-232. Studies in Archeology 21. Texas Archeological Research Laboratory, The University of Texas at Austin.

Good, C. E.

1982 Analysis of Structures, Burials, and Other Cultural Features. In The Deshazo Site, Nacogdoches County, Texas, Vol. 1: The Site, Its Setting, Investigation, Cultural Features, Artifacts of Non-Native Manufacture, and Subsistence Remains, edited by D. A. Story, pp. 51-110. Texas Antiquities Permit Series 7. Texas Antiquities Committee, Austin.

Johnson, L., Jr,

1992 Stealing Secrets from Dead Potters: A Plea for Painstaking Ceramic Sleuthing. APR News \& Views 4(1):16-19. Department of Archeological Planning \& Review, Texas Historical Commission, Austin.

Kelley, D. B., T. K. Perttula, D. G. Hunter, B. Nelson, B. M. Albert, J. Kelly, and D. E. Wilson

2006 Interim Report on Archaeological Data Recovery at 41AN38, Anderson County, Texas. Coastal Environments, Ine., Baton Rouge, Louisiana.

Kleinschmidt, U. K. W.

1982 Review and Analysis of the A. C. Saunders Site, 41AN19, Anderson County, Texas. Master's thesis, Department of Anthropology, The University of Texas at Austin.

La Vere, D.

1998 Life among the Texas Indians: The WPA Narratives. Texas A\&M University Press, College Station.

Perttula, T. K. (editor)

2005 Archeological Investigations at the Pilgrim's Pride Site (4ICP304), a Titus Phase Community in the Big Cypress Creek Basin, Camp County, Texas. 2 Vols. Report of Investigations No. 30. Archeological \& Environmental Consultants, LLC, Austin.

Perttula, T. K. and B. Nelson

2003 The Nawi haia ina Site (4IRK170): Archeological Investigations in the City of Henderson's Southside Wastewater Treatment Plant, Rusk County, Texas. Report of Investigations No. 51. Archeological \& Environmental Consultants, LLC, Austin. 
2006 Test Excavations at Three Caddo Sites at Mission Tejas State Park, Houston County, Texas. Report of Investigations No. 76. Archeological \& Environmental Consultants, LLC.

2007 Archeological Survey Investigations and Test Excavations at $41 C E 354$ at the North and South Lake areas of the H.R.C. Cherokee Tree Farm, L.P. Project, Cherokee County, Texas. Report of Investigations No. 80. Archeological \& Environmental Consultants, LLC, Austin.

Rice, P. M.

1987 Pottery Analysis: A Sourcebook. University of Chicago Press, Chicago.

1996 Recent Ceramic Analysis: 1. Function, Style, and Origins. Journal of Archaeological Research 4(2):133-163.

Story, D. A. (editor)

1995 The Deshazo Site, Nacogdoches County, Texas, Volume 2: Artifacts of Native Munufacture. Studies in Archeology 21. Texas Archeological Research Laboratory, The University of Texas at Austin.
Suhm, D. A. and E. B. Jelks (editors)

1962 Handbook of Texas Archeology: Type Descriptions. Initial Series of Descriptions. Special Publication No. 1, Texas Archeological Society, and Bulletin No. 4, Texas Memorial Museum, Austin.

Teltser, P. A.

1993 An Analytic Strategy for Studying Assemblage-Scale Ceramic Variation: A Case Study from Southeast Missouri. American Antiquity 58(3):530-543.

Varien, M. D.

1999 Sedentism and Mohility in a Social Landscape: Mesa Verde and Beyond. University of Arizona Press, Tucson. 